\title{
Synthesis and Characterization of Gold Nanoparticles from Nostoc sp. strain HKAR-2 and their In Vitro Antibacterial, Antifungal, and Antitumor Potentials
}

\author{
Arun S. Sonker ${ }^{1}\left(\mathbb{D}\right.$, Jainendra Pathak ${ }^{2} \mathbb{D}$, Richa ${ }^{1}(\mathbb{D})$, Rajeshwar P. Sinha ${ }^{1, *(\mathbb{D})}$ \\ 1 Laboratory of Photobiology and Molecular Microbiology, Centre of Advanced Study in Botany, Institute of Science, \\ Banaras Hindu University, Varanasi-221005, India; rpsinhabhu@ gmail.com (R.P.S.); \\ 2 Department of Botany, Pt. Jawaharlal Nehru College (Affiliated to Bundelkhand University), Banda-210001, India \\ * Correspondence: rpsinhabhu@gmail.com (R.P.S.);
}

Scopus Author ID 35485458700

Received: 5.05.2021; Revised: 10.06.2021; Accepted: 14.06.2021; Published: 27.06.2021

\begin{abstract}
In the present study, gold nanoparticles (AuNPs) have been synthesized through biological methods using the cell-free extracts of cyanobacterium Nostoc sp. strain HKAR-2 isolated from the hot spring of India. To determine morphological, structural, and optical properties of green synthesized AuNPs, UV-VIS spectroscopy, FTIR, X-ray diffraction, scanning electron microscopy (SEM), and transmission electron microscopy-selected area electron diffraction (TEM-SAED) were used. Spectroscopic analysis showed the absorbance peak at $540 \mathrm{~nm}$ due to the reduction of $\mathrm{Au}^{3+}$ to $\mathrm{Au}^{0}$ by cyanobacterial extract, which indicated surface plasmon resonance (SPR) of the synthesized AuNPs. Characteristic Bragg peaks at (111), (200), (220), and (311) facets of the face center cubic (fcc) confirmed the crystalline nature of AuNPs in the XRD pattern. FTIR results indicated the role of proteins and amino acids in the reduction of $\mathrm{Au}^{3+}$ to $\mathrm{Au}^{0}$ as well as for the stability of AuNPs. Zeta potential confirmed a charge of $-2.39 \mathrm{Mv}$ on the AuNPs. SEM and TEM results confirmed the large agglomerated shape of AuNPs with sizes ranging between 10-100 nm. Their antibacterial, antifungal and anticancerous properties were also studied against plant bacterial strains, fungal strains, and MCF7 cells, respectively. AuNPs also showed dose-dependent cytotoxic activity against human breast cancer MCF-7 cells with $\mathrm{IC}_{50}$ of $250 \mu \mathrm{g} / \mathrm{mL}$.
\end{abstract}

Keywords: cyanobacteria; gold nanoparticles; MCF-7 cells; anticancerous; antibacterial; antifungal properties.

(C) 2021 by the authors. This article is an open-access article distributed under the terms and conditions of the Creative Commons Attribution (CC BY) license (https://creativecommons.org/licenses/by/4.0/).

\section{Introduction}

Metal nanoparticles (NPs) are novel compounds that show significant biological activity and are used to diagnose and treat several types of disease, especially in cancer [1-8]. Gold nanoparticles (AuNPs) have unique physical, chemical, and biological properties compared to other metal NPs like silver and zinc NPs $[9,10]$. The properties of NPs depend upon their unique shape and size [11,12]. Due to the different shapes and sizes of AuNPs, they are used in different areas like electronics, catalysis, decorative coatings and paints, pollution control, cancer therapy, drug delivery, biomedical assay, biosensor, bio-imaging, etc. [13-19]. Due to the unique properties of AuNPs, they are also used in the manufacturing of biosensors, DNA labeling, and vapor sensing [20-22]. For the synthesis of AuNPs, several chemical methods are used, but the byproduct of these chemical methods is very toxic and may affect 
humans and the environment [23,24]. To overcome these problems, the biological method is more suitable for the synthesis of AuNPs. Several biological materials such as microorganisms [25], enzymes [26], fungi [27], and plants or plant extracts [28] have been used to synthesize NPs, which are an alternative for chemical and physical methods. Cyanobacteria are a great source of fine chemicals, pharmaceuticals, biofuels, several pigments, and proteins [29-31] and are the more preferred candidate for NPs synthesis in comparison to other biological materials as they can grow rapidly in a very short period of time, produce higher biomass and are able to accumulate high amount of metal and absorbed $\mathrm{CO}_{2}$ and hence could be more economical $[3,6]$. Some cyanobacteria and algal genera such as Plectonema boryanum have been reported for bioconversion of $\mathrm{Au}^{3+}$ to $\mathrm{Au}^{0}$. Algal biomass can be easily harvested, and the intracellular NPs can be released by disrupting the cells by commercially available processing equipment [32]. Cyanobacteria such as Anabaena, Calothrix, and Leptolyngbya have been reported to synthesize intracellular gold [33], silver, palladium, and platinum NPs [34]. Some researchers also used the whole mass of filamentous cyanobacteria Plectonema boryanum (strain UTEX 485) to synthesize AuNPs [32]. Extraction of NPs formed inside the cell is a very complex process and not very cost-effective. The cyanobacterial extract contains multiple types of bioactive molecules that aid in the synthesis and stabilization of the NPs [29]. Hence, we used a cell-free extract of Nostoc sp. strain HKAR-2 for the synthesis of NPs. Nostoc sp. strain HKAR-2 has been isolated from hot springs of Rajgir, India, and grows easily in the inorganic medium in the laboratory. This is probably the first report of utilizing the cell extracts of a hot spring cyanobacterium to synthesize AuNPs.

\section{Materials and Methods}

\subsection{Preparation of aqueous cyanobacterial cell-free extract.}

The filamentous cyanobacterium Nostoc sp. strain HKAR-2, isolated from the hotspring of Rajgir, India [35], was taken for the formation of cell extract. Cultures were grown in BG-11 medium without any nitrogen source $\left(\mathrm{pH}\right.$ 7.0) at $20 \pm 2{ }^{\circ} \mathrm{C}$ under illumination with daylight fluorescent tubes at a photon flux density of $94 \mu \mathrm{mol}$ photon $\mathrm{m}^{-2} \mathrm{~s}^{-1}$ at the surface of vessels with a 14/10 light/ dark cycle [36]. Growth was analyzed by measuring optical density at $750 \mathrm{~nm}$. Exponentially growing cultures were used for the preparation of cell extract. To prepare the cell extract, $200 \mathrm{~mL}$ double-distilled water (DDW) was added to the $5 \mathrm{~g}$ dry weight of the cyanobacterium. This mixture was heated up to $70{ }^{\circ} \mathrm{C}$ for one hour. After heating, the mixture was allowed to cool at room temperature, followed by centrifugation at 10,000 rpm for 30 minutes. After centrifugation, the supernatant was collected and stored at $4{ }^{\circ} \mathrm{C}$ for further use [3].

\subsection{Biosynthesis of AuNPs.}

$3 \mathrm{~mL}$ of $0.001 \mathrm{mM}$ gold chloride $(\mathrm{HAuCl} 4)$ solution was added to $30 \mathrm{~mL}$ of cell-free cyanobacterial extract to initiate the experiments. The mixture was incubated at $25^{\circ} \mathrm{C}$ for 120 h. The synthesis of AuNPs was indicated by a change in the color of the whole solution. In the control treatment, no $\mathrm{HAuCl}_{4}$ was added to the cyanobacterial extract. DDW was used as blank. For the synthesis of AuNPs different parameters such as temperature (20, 40, 60, 80, 100, and $\left.120{ }^{\circ} \mathrm{C}\right)$ different reaction conditions like $\mathrm{pH}(3,5$ and 7), different extract volume $(5,10,15$, 20, and $25 \mathrm{~mL}$ ), different $\mathrm{HAuCl}_{4}$ concentration $(0.001,0.002,0.003,0.004$, and $0.005 \mathrm{mM}$ ) 
different environmental conditions (dark, light, $4^{0} \mathrm{C}$ and $-20^{\circ} \mathrm{C}$ ) and different time intervals $(0$, $24,48,72,96$, and $120 \mathrm{~h}$ ) were optimized.

\subsection{Characterization of AuNPs.}

\subsubsection{Ultraviolet-Visible (UV-VIS) spectroscopy.}

The bioreduction of precursor gold ions was monitored by spectroscopic analysis of the aliquots $(3 \mathrm{~mL})$ at desired time intervals. Absorption measurements in the range of 200-1100 $\mathrm{nm}$ were carried out using UV-VIS double beam spectrophotometer (2900 Hitachi, Japan) at a resolution of $1 \mathrm{~nm}$.

\subsubsection{Fourier transformed infrared spectroscopy (FTIR).}

To check the biomolecular capping on to the surface of AuNPs, then centrifuged and dried samples of AuNPs were subjected to FTIR (Varian 3100 FTIR spectrophotometer) analysis. For FTIR, a small amount of dried biomass was ground with a $\mathrm{KBr}$ pellet at room temperature with a resolution of $4 \mathrm{~cm}^{-1}$ and the range of $400-4000 \mathrm{~cm}^{-1}$. The FTIR spectra of the cyanobacterial cell-free extract were taken before and after the synthesis of AuNPs.

\subsubsection{Size distribution and zeta potential.}

The particle size distribution was done using dynamic light scattering (DLS) measurement, and the zeta potential value of the AuNPs (suspended in Mili Q water) were determined by using Beckman coulter Delta Nano C particle size analyzer (Beckman Coulter Inc., USA). The AuNPs were dissolved in physiological saline for zeta potential analysis. Data obtained were analyzed using Zetasizer software.

\subsubsection{Scanning electron microscopy (SEM).}

The morphology and particle size of the AuNPs were characterized using SEM. Briefly, a thin film of the sample was prepared on a carbon-coated copper grid by dropping a very small amount of the sample on the grid, and the extra solution was removed using a blotting paper. The film on the SEM grid was then dry by putting it under a mercury lamp for $5 \mathrm{~min}$. SEM microphotographs were taken in the scanning electron microscope (Quanta-200 FEI, Netherland).

\subsubsection{Transmission electron microscopy (TEM).}

The size of the green synthesized AuNPs was determined using transmission electron microscopy (TECNAI G2-TWIN-FEI TEM). The sample was prepared by sonicating the biosynthesized AuNPs, and after that, a drop of the aqueous sample was placed on a carboncoated copper grid formvar coated. It was then dried under an infrared lamp before photography. TEM operated at an accelerating voltage of $200 \mathrm{Kv}$.

\subsubsection{X-ray diffraction (XRD) analysis.}

The XRD analysis (PAN analytical X pert PRO Model) was done to determine the dimension of biologically synthesized AuNPs with h, k, l value. First, the aqueous suspension of AuNPs (45 mL) was centrifuged for 10,000 rpm for $30 \mathrm{~min}$, and the pellet was dissolved in 
$5 \mathrm{~mL}$ DDW. The suspension was then lyophilized (Christ Alpha 1-2 LD plus), and the diffraction pattern was operated at $40 \mathrm{kV}$ and $30 \mathrm{~mA}$ in $\mathrm{Cu}$, Ka radiation. Next, the particle size ( $\mathrm{L}$ ) of AuNPs was calculated using following Debye-Scherer's equation: $L=0.9 \lambda / \beta \cos \theta$, where, $\lambda$ is the wavelength of the $X$-ray, $\beta$ is full width, and half maximum and $\theta$ is the Bragg's angle.

\subsection{In vitro cytotoxicity.}

Proliferation/survival of cells after AuNPs exposure was assessed by 3-[4, 5dimethylthiazol-2-yl] 2, 5-diphenyltetrazolium bromide assay (MTT) (purchased from SigmaAldrich Company, St. Louis, MO). Briefly, an exponentially growing MCF-7 cell line was seeded in 24 well plates (with a density of 40,000 cells/well $/ 2 \mathrm{~mL}$ media) and incubated at 37 ${ }^{\circ} \mathrm{C}$ for adherence to the bottom of the plate. After $18 \mathrm{~h}$, the media was replaced with $2 \mathrm{~mL}$ fresh complete DMEM media. Sterile phosphate buffer saline (PBS) $(20 \mu \mathrm{L})$ containing varying concentrations of AuNPs were added to each well and incubated at $37{ }^{\circ} \mathrm{C}$. A plate with AuNPfree phosphate-buffer saline served as control. After $48 \mathrm{~h}$ exposure of NPs, cells were washed with sterile PBS to remove NPs to prevent any interference with the MTT reagent. Fresh complete DMEM media $(500 \mu \mathrm{L})$ containing $0.4 \mu \mathrm{g}$ of MTT reagent was added to each well, and the plate was incubated at $37^{\circ} \mathrm{C}$. After $5 \mathrm{~h}$, MTT solution in the medium was aspirated off. To achieve solubilization of formed formazan crystals, $500 \mu \mathrm{L}$ of DMSO was added. The microtiter plate was shaken for $10 \mathrm{~min}$, and the purple color of formazan crystals was calculated by measuring optical density (OD) at $570 \mathrm{~nm}$ by using a microplate reader (Spectra Max M2, MTX Lab System). The OD at $630 \mathrm{~nm}$ was also observed and measured OD was calculated by subtracting the OD at $630 \mathrm{~nm}$ to at $570 \mathrm{~nm}$ for background correction. Anticancer activity was expressed with respect to the number of viable cells, i.e., anticancer activity is indirectly proportional to the number of viable cells, which is directly proportional to optical density. Measured OD of cells without any treatment of drug was taken as control. Using the control OD values, the percent inhibition at each test agent concentration was calculated by dividing the observed OD value by control OD value and multiplying by 100 . The anti-proliferative activity of AuNPs is expressed as the $50 \%$ inhibitory concentration $\left(\mathrm{IC}_{50}\right)$. $\mathrm{IC}_{50}$ is defined as the concentration of the test agent that results in a 50\% decrease in the control level of proliferation.

\subsection{Antibacterial activity by well diffusion method.}

The biosynthesized AuNPs were tested for their antibacterial activity by well diffusion method against plant pathogenic bacteria, such as Ralstonia solanacearum and Xanthomonas campestris. The pure cultures of these organisms were routinely sub-cultured on a nutrient agar medium at $37{ }^{\circ} \mathrm{C}$ on a rotary shaker at $200 \mathrm{rpm} .100 \mu \mathrm{L}$ of each strain were swabbed uniformly on the individual plates using a sterile glass spreader. Defined wells ( $3 \mathrm{~mm}$ ) were made on nutrient agar plates using a cork borer. Using a micropipette, different concentrations $(50,100$, and $150 \mu \mathrm{L}$ ) of AuNPs solution were poured into separate wells on the plates. A number of antibiotics were tested for the sensitivity towards the two bacterial strains. Among all the tested antibiotics, only streptomycin $(25 \mu \mathrm{g} / \mathrm{mL})$ was selected as a positive control for this study. DDW was taken as a negative control. The plates were then incubated at $37{ }^{\circ} \mathrm{C}$ for the desired time interval (overnight), and the different levels of the zone of inhibition were measured. 


\subsection{Antifungal activity by well diffusion method.}

For screening of antifungal activity of AuNPs, a loopful of two fungal strains, such as Aspergillus niger and Trichoderma harzianum were placed in the center of potato dextrose agar (PDA) plates. Wells of size $3 \mathrm{~mm}$ were made on the plates using a cork borer and were filled with100 $\mu \mathrm{L}$ of NPs solution. Cumin oil $(0.6 \mu \mathrm{L} / \mathrm{mL})$ was used as a positive control [37] and DDW as a negative control. The plates were then incubated at $35^{\circ} \mathrm{C}$ for $18 \mathrm{~h}$, and the different levels of the zone of inhibition were measured.

\subsection{Statistical analysis.}

The experiments were repeated thrice for the accuracy of the results. All results are presented as mean values of three replicates, and statistical analyses were done by one-way analysis of variance.

\section{Results and Discussion}

\subsection{Confirmation of biosynthesized NPs by UV-visible spectroscopy.}

The addition of cyanobacterial cell-free extract to $0.001 \mathrm{mM} \mathrm{HAuCl}_{4}$ resulted in a color change of the solution from light green to dark ruby red after $124 \mathrm{~h}$ (Figure 1a-c) due to the production of AuNPs.

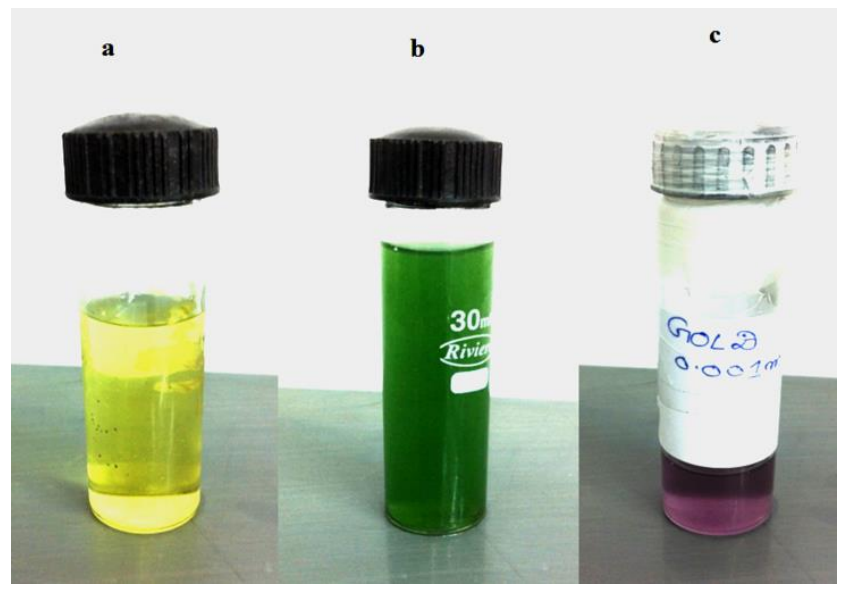

Figure 1. Change in color of solutions after $124 \mathrm{~h}$ of incubation. (a) $0.001 \mathrm{mM}$ gold chloride solution (Light yellow); (b) Cell-free extract of Nostoc sp. strain HKAR-2 (greenish); (c) Biosynthesized AuNPs showing light ruby red color developed due to the bioreduction of $\mathrm{Au}^{3+}$ to $\mathrm{Au}^{0}$.

The intensity of color increased with the time of incubation, where a maximum change in color (light ruby red) was measured at $124 \mathrm{~h}$ (Figure 1c). The light ruby red color appears due to the surface plasmon of the biosynthesized AuNPs. As the incubation time increased, the intensity of light ruby red changed into dark ruby red, which is the indication for the synthesis of AuNPs. UV-VIS spectra are one of the most sensitive, easy, and primary methods to check the synthesis of AuNPs. The absorbance of the sample was recorded between 200-1100 nm by using a Hitachi-2000 UV-visible spectrophotometer. The solution yielded an absorbance peak centered at $540 \mathrm{~nm}$ (Figure 2). This peak is developed due to the bioreduction of $\mathrm{Au}^{3+}$ to $\mathrm{Au}^{0}$. 


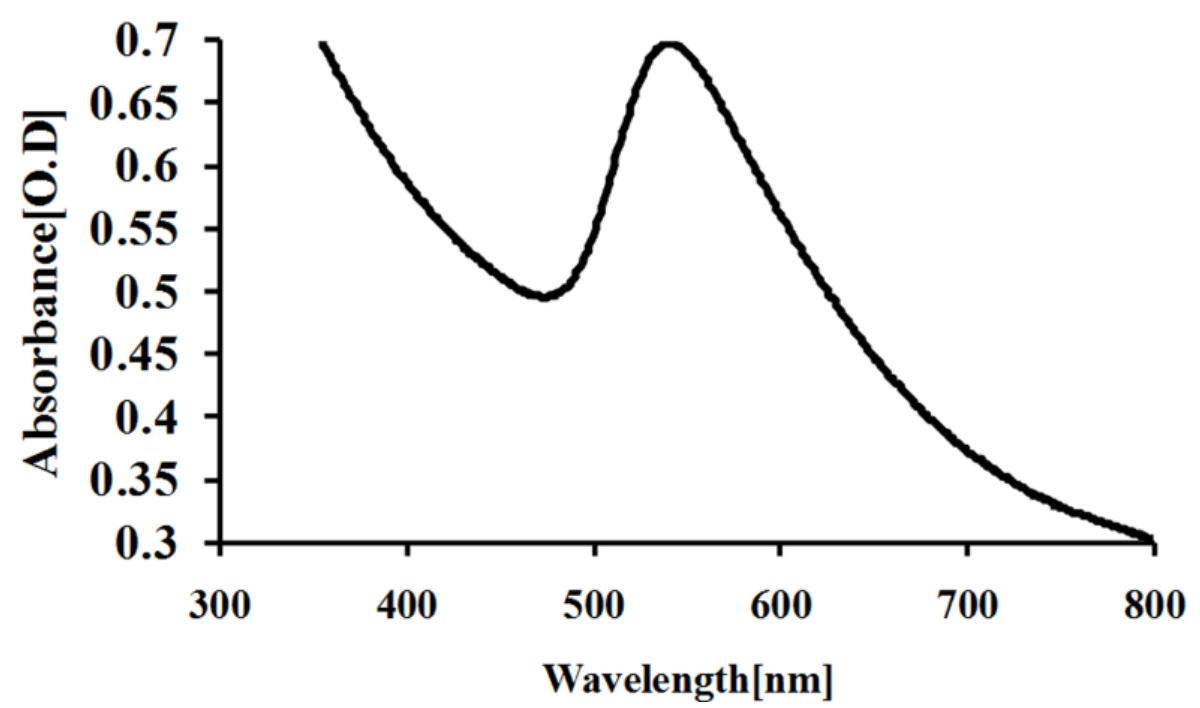

Figure 2. UV-Visible absorption spectrum of AuNPs synthesized from the cell-free extract of Nostoc sp. strain HKAR-2 having peak centered at $540 \mathrm{~nm}$ after $124 \mathrm{~h}$.

The absorption peak was recorded at the time intervals of $0,24,48,72,96$, and $124 \mathrm{~h}$ (Figure 3). The peak area increased at $540 \mathrm{~nm}$ with increasing time intervals, which indicated the increased synthesis of AuNPs. As time progressed, the peak at $540 \mathrm{~nm}$ got sharper and narrower due to the rapid production of AuNPs. The best condition for the maximum synthesis of AuNPs was at room temperature on $\mathrm{pH}=7$, by mixing the $30 \mathrm{~mL}$ of the cyanobacterial cellfree extract with $3 \mathrm{~mL}$ of $0.001 \mathrm{mM} \mathrm{HAuCl}_{4}$ solution with continuous stirring for $3 \mathrm{~h}$. It was noted that the bioreduction of $\mathrm{Au}^{3+}$ to $\mathrm{Au}^{0}$ started just after $1 \mathrm{~h}$ of the addition of $0.001 \mathrm{mM}$ $\mathrm{HAuCl}_{4}$ solution into the cell-free extract, and reduction of $\mathrm{HAuCl}_{4}$ solution completed after $124 \mathrm{~h}$.

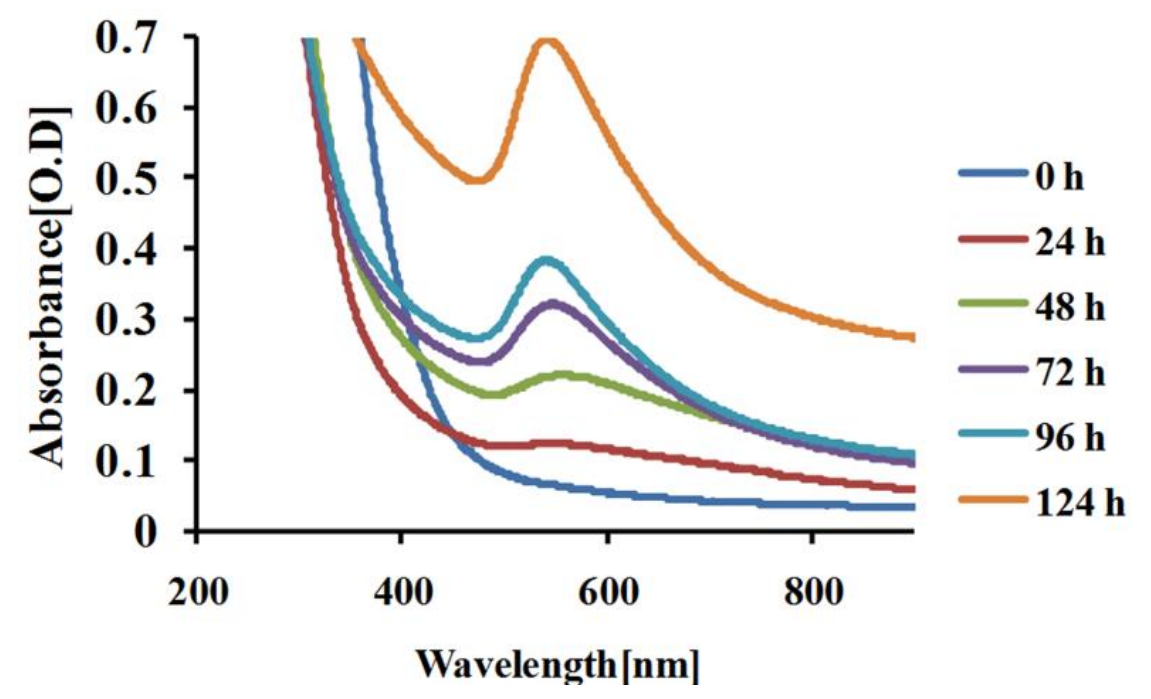

Figure 3. UV-Vis spectra recorded at different time intervals from the aqueous solution of gold chloride solution with the cell-free cyanobacterial extract.

\subsection{FTIR spectral analysis.}

FTIR analysis of the air-dried cell extract and AuNPs showed a number of peaks representing different functional groups (Figure 4a, b). The FTIR spectra of a dried sample of the cell-free cyanobacterial extract showed intensive peaks at $3396.25 \mathrm{~cm}^{-1}(\mathrm{O}-\mathrm{H}), 2959 \mathrm{~cm}^{-1}$ $\left(\mathrm{CH}_{3}\right), 2923.19 \mathrm{~cm}^{-1}(\mathrm{C}-\mathrm{N})$ and $1658.5 \mathrm{~cm}^{-1}(\mathrm{C}=\mathrm{O})$ (Figure 4a). FTIR analysis of green synthesized AuNPs (Figure 4b) showed peaks at $3382.48 \mathrm{~cm}^{-1}(\mathrm{O}-\mathrm{H}), 2925.14 \mathrm{~cm}^{-1}(\mathrm{C}-\mathrm{N})$, $1633.2 \mathrm{~cm}^{-1}$ (Amide-I), $1423.65 \mathrm{~cm}^{-1}(\mathrm{COOH}), 1383.63 \mathrm{~cm}^{-1}(\mathrm{~N}-\mathrm{O})$ and $1075.91 \mathrm{~cm}^{-1}(\mathrm{C}-\mathrm{O})$. 

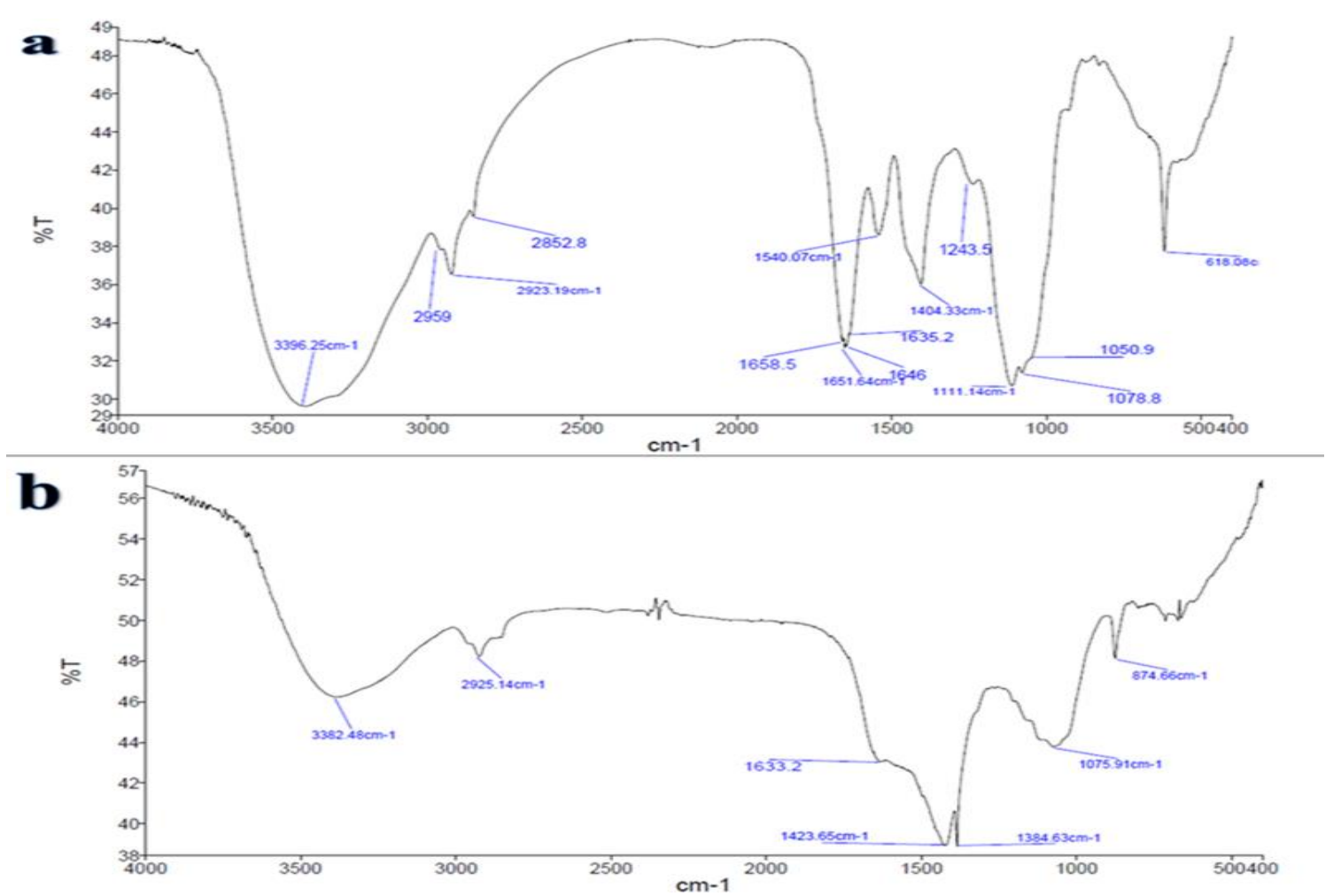

Figure 4. FTIR spectra of freeze-dried samples of AuNPs. (a) Cell-free extract of Nostoc sp. strain HKAR-2 without gold chloride (control); (b) AuNPs synthesized by bioreduction of $0.001 \mathrm{mM}$ gold chloride solution in the presence of the cell-free extract of Nostoc sp. strain HKAR-2 after $124 \mathrm{~h}$.

\subsection{XRD pattern of biosynthesized AuNPs.}

The nature of the AuNPs formed from the cell-free extract of Nostoc sp. strain HKAR2 was detected by using XRD (Figure 5). The peak at $2 \theta$ values of $38.22^{\circ}, 44.50^{\circ}, 64.66^{\circ}$, and $77.62^{0}$ corresponded to (111), (200), (220), and (311) planes for AuNPs. Further analysis with TEM also confirmed the size of the biosynthesized AuNPs.

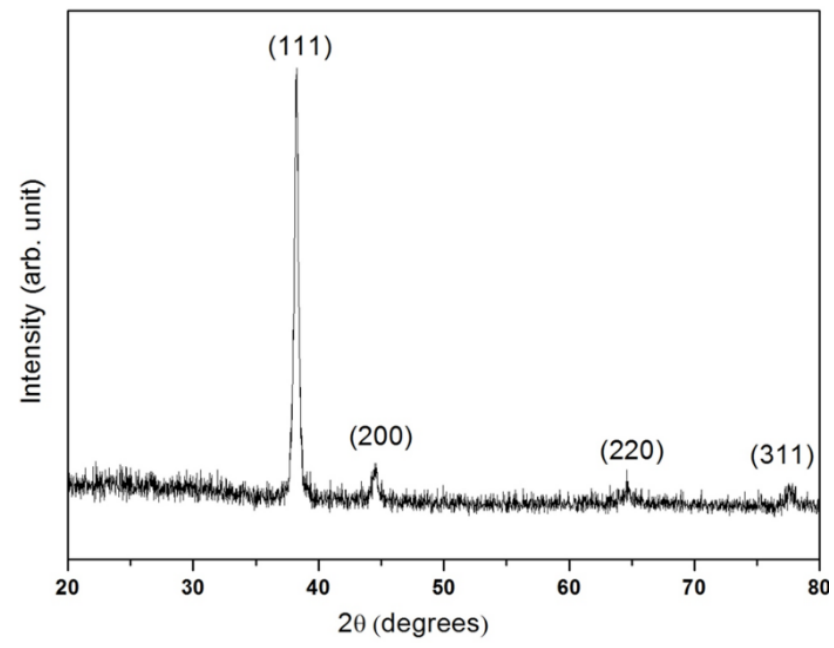

Figure 5. XRD pattern of AuNPs showing the facets of crystalline AuNPs after bioreduction.

\subsection{Zeta potential and DLS analysis of AuNPs.}

The Zeta potential of biosynthesized NPs is $-2.39 \mathrm{mV}$ (Figure 6), and this charge indicates its stability. The zeta potential mainly depends upon the $\mathrm{pH}$ and the electrolytic concentration of the dispersion [38]. The above data support the stability of NPs in 
physiological saline $\mathrm{pH}$. DLS data showed the size distribution of particles with maximum intensity at $255.8 \mathrm{~nm}$ with a layer of hydration (Figure 7).

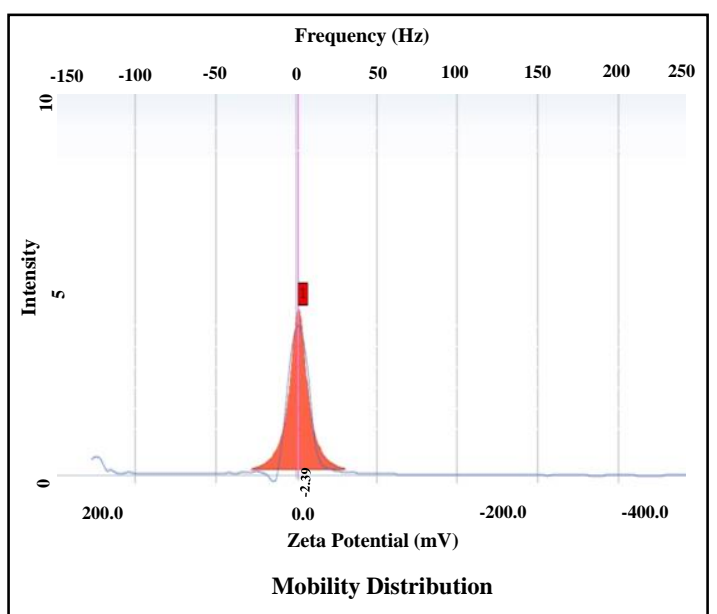

Figure 6. Biosynthesized AuNPs with a charge of $-2.39 \mathrm{mV}$ indicating their stability.



Figure 7. Average hydrodynamic size of AuNPs $(255.5 \mathrm{~nm})$ in liquid medium by DLS method.

\subsection{SEM analysis of biosynthesized AuNPs.}

SEM images of biosynthesized AuNPs confirmed these particles to be small and beadshaped (Figure 8a-f).

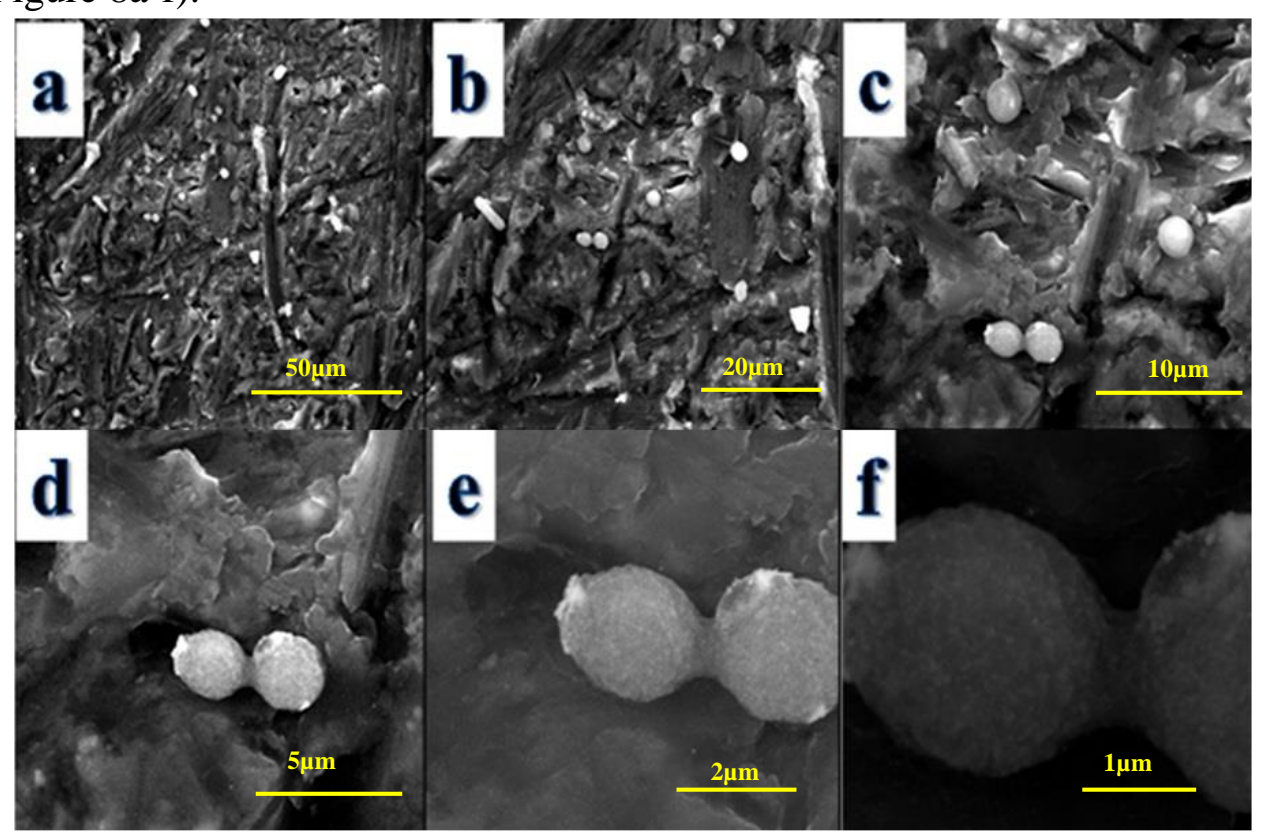

Figure 8. SEM micrograph images of AuNPs at different magnifications synthesized by the green method using cell-free extract of Nostoc sp. strain HKAR-2 showing the small bead-like structure, which is aggregated into the larger structure. 
3.6. Size analysis of green synthesized AuNPs by TEM.

TEM images showed the size of NPs in the range of 10-100 nm, i.e., $10 \mathrm{~nm}$ (Figure 9a), $20 \mathrm{~nm}$ (Figure 9b), $50 \mathrm{~nm}$ (Figure 9c), and $100 \mathrm{~nm}$ (Figure 9d), respectively. The TEM-SAED showed the pattern of AuNPs, which indicated the face cubic centered (fcc) crystalline nature of the AuNPs (Figure 9e-h).

\subsection{Antitumor activity of AuNPs against MCF-7 breast cancer cell lines.}

MTT assay was done to analyze the cytotoxic effect of green synthesized AuNPs on the proliferation of MCF-7 cells. The dose-dependent cytotoxicity was observed in AuNPs treated MCF-7 cells. The 0, 5, 100, 250, 500, and $1000 \mu \mathrm{g} / \mathrm{mL}$ concentration of AuNPs were exposed to MCF-7 cells for $24 \mathrm{~h}$. Biosynthesized NPs were dissolved in buffer, which was taken as a negative control for MCF-7. However, the cytotoxic effect of biosynthesized AuNPs against MCF-7 cells did not show significant cytotoxicity at lower concentrations, and cytotoxicity increased with increasing concentration from 5 to $1000 \mu \mathrm{g} / \mathrm{mL}$, respectively (Figure 10). The $\mathrm{IC}_{50}$ for AuNPs was found to be $250 \mu \mathrm{g} / \mathrm{mL}$.

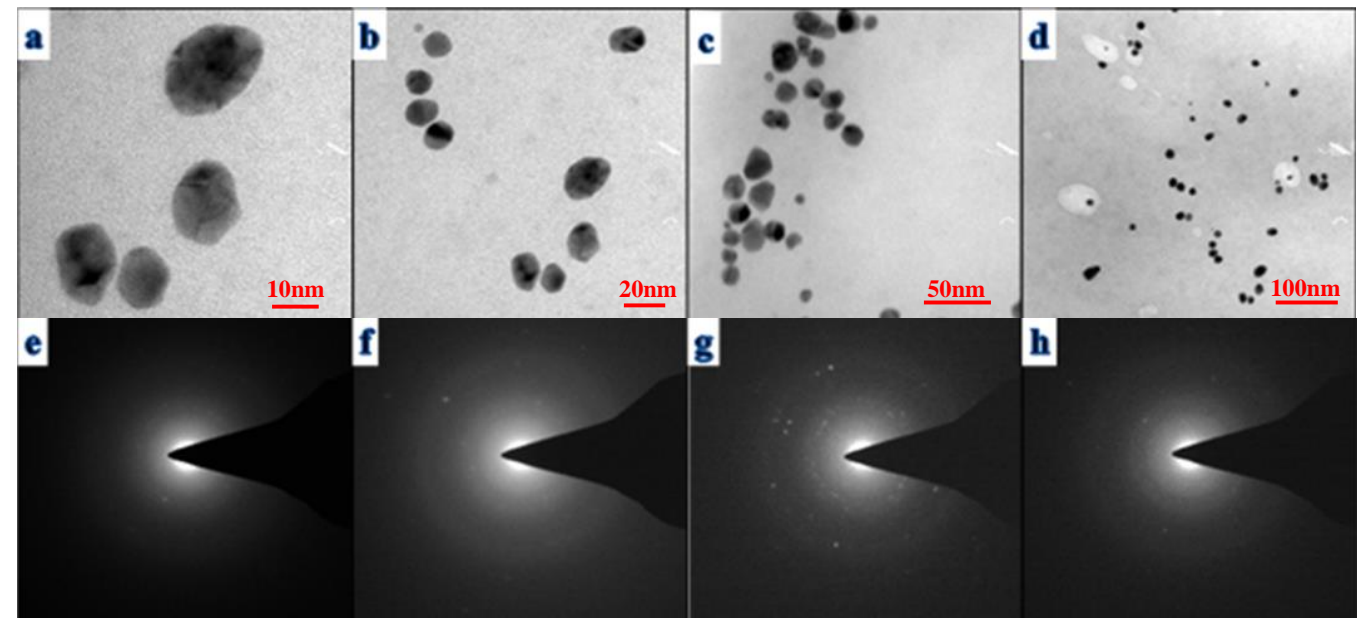

Figure 9. HRTEM images of AuNPs recorded on the carbon-coated copper grid, which was synthesized by using an aqueous mixture of cell-free extract of Nostoc sp. strain HKAR-2 and $0.001 \mathrm{mM}$ gold chloride solution. (a) AuNPs with an average size of $10 \mathrm{~nm}$; (b) AuNPs with an average size of $20 \mathrm{~nm}$; (c) AuNPs with an average size of $50 \mathrm{~nm}$; (d) AuNPs with an average size of $100 \mathrm{~nm}$; (e-h) TEM-SEAD ring pattern showing (face-cubic centered) the circular packed crystalline nature of AuNPs.

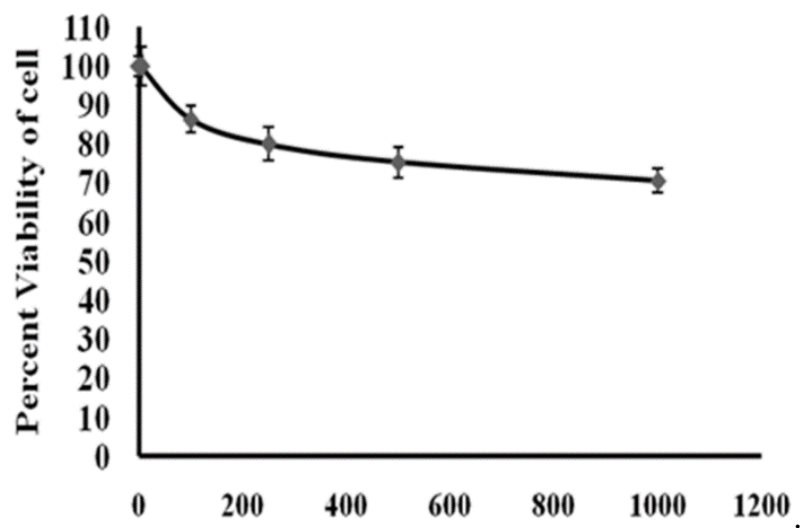

Figure 10. MTT assay results confirming the in vitro anticancerous effect of AuNPs against the MCF-7 cell line. Triplicates of each sample were analyzed in MTT assay, and experiments were repeated at least three times on different days. Results with a p-value less than 0.5 were considered statistically significant. The percentage of cytotoxicity is expressed relative to untreated controls. 


\subsection{Antibacterial activity of AuNPs against plant bacterial strain.}

The antimicrobial activity of biosynthesized AuNPs was investigated against two plant pathogenic bacteria, i.e., $R$. solanacearum and $X$. campastris, using the well diffusion method. The diameter of inhibition zones ( $\mathrm{mm}$ ) around each well with AuNPs solution is shown in Table 1. The antibacterial activity of AuNPs was found to be highest against $R$. solanacearum and $X$. campastris $(\sim 10 \mathrm{~mm})$ at $15 \mu \mathrm{g} / \mathrm{mL}$ concentration of AuNPs (data not shown). DDW was taken as a negative control for both of the plant bacterial strains, and they do not show any zone of inhibition, whereas antibiotic streptomycin served as a positive control.

Table 1. Zone of inhibition for AuNPs derived from the cell-free extract of cyanobacterium Nostoc sp. strain HKAR-2 against plant pathogenic bacterial strains.

\begin{tabular}{c|c|c|c|c}
\multirow{2}{*}{ Bacteria } & $\begin{array}{c}\text { Concentration of } \\
\text { AuNPs }(\boldsymbol{\mu g} / \mathbf{m L})\end{array}$ & AuNPs & $\begin{array}{c}\text { Positive control } \\
\text { (Streptomycin) }\end{array}$ & $\begin{array}{c}\text { Negative } \\
\text { control } \\
\text { (DDW) }\end{array}$ \\
\hline \multirow{3}{*}{$\begin{array}{c}\text { Ralstonia } \\
\text { solanacearum }\end{array}$} & 5 & $5 \pm 0.5$ & 35 & 0 \\
\cline { 2 - 3 } & 10 & $5 \pm 1.0$ & & \\
\cline { 2 - 3 } $\begin{array}{c}\text { Xanthomonas } \\
\text { campestris }\end{array}$ & 15 & $10 \pm 2.0$ & & \multirow{2}{*}{0} \\
\cline { 2 - 3 } & 5 & $5 \pm 0.5$ & & \\
\cline { 2 - 3 } & 10 & $10 \pm 0.5$ & & \\
\end{tabular}

All bacteria were grown under identical conditions and the experiments were performed in triplicate. Plates found with any contamination were immediately discarded. Values represent the mean \pm SD.

\subsection{Antifungal activity of AuNPs against two fungal strains.}

For the in vitro antifungal activity, Cuminum cyminum (L.) seed essential oil, which is an antifungal [37] agent, was used as a positive control for A. niger and T. harzianum, and DDW was used as a negative control for A. niger and T. harzianum (data not shown). The diameter of inhibition zones for A. niger was found to be 3, 5, and 8 and 4, 5, and $9 \mathrm{~mm}$ for $T$. harzianum at 5, 10, and $15 \mu \mathrm{g} / \mathrm{mL}$ concentration of biosynthesized AuNPs, respectively (Table 2). Whereas there was no fungal growth in the presence of cumin oil, which was taken as a positive control for both the fungal strains and negative control, shows the growth of fungi in which DDW was added (Table 2).

Table 2. Zone of inhibition for AuNPs derived from the cell-free extract of cyanobacterium Nostoc sp. strain HKAR-2 against two fungal strains.

\begin{tabular}{c|c|c|c|c}
\multirow{2}{*}{ Fungal strains } & \multicolumn{2}{c}{$\begin{array}{c}\text { Concentration of } \\
\text { AuNPs }(\boldsymbol{\mu g} / \mathbf{m L})\end{array}$} & \multicolumn{2}{c}{ Zone of Inhibition (mm) } \\
\hline \multirow{3}{*}{ Aspergillus niger } & & AuNPs & $\begin{array}{c}\text { Positive control } \\
\text { (Cumin oil) }\end{array}$ & $\begin{array}{c}\text { Negative } \\
\text { control } \\
\text { (DDW) }\end{array}$ \\
\cline { 2 - 3 } & 5 & $3 \pm 0.3$ & \multirow{2}{*}{$\begin{array}{c}\text { Full inhibition of } \\
\text { growth }\end{array}$} & Full growth \\
\cline { 2 - 3 } & 10 & $5 \pm 0.6$ & \\
\hline \multirow{2}{*}{$\begin{array}{c}\text { Trichoderma } \\
\text { harzianum }\end{array}$} & 15 & $8 \pm 0.4$ & \multirow{2}{*}{$\begin{array}{c}\text { Full inhibition of } \\
\text { growth }\end{array}$} & \multirow{2}{*}{ Full growth } \\
\cline { 2 - 3 } & 5 & $5 \pm 0.4$ &
\end{tabular}

All fungal strains were grown under identical conditions and the experiments were performed in triplicate. Plates found with any contamination were immediately discarded. Values represent the mean \pm SD. 


\section{Discussion}

Biosynthesis of AuNPs has been an active area of research [39-42], and several workers have reported the synthesis of these NPs from cyanobacteria [43-46]. In the present research, first time, AuNPs are synthesized using cell-free extract of Nostoc sp. strain HKAR-2 isolated hot spring of India. The cell-free extract of Nostoc sp. strain HKAR-2 is capable of reducing gold chloride solution to AuNPs $\left(\mathrm{Au}^{3+}\right.$ to $\left.\mathrm{Au}^{0}\right)$. When the cyanobacterial extracts were mixed with $0.001 \mathrm{mM}$ gold chloride solution, the color of the solution changed from light green to dark ruby red. The ruby red color is generated due to the formation of spherical NPs, and the bluish color is generated due to the nanorod [43]. Grace and Pandian (2007)[47] reported that the formation of color is the characteristic of AuNPs. The color change occurs due to the phenomenon of surface plasmon resonance. The synthesis of AuNPs is also confirmed by the UV-VIS absorption spectra, in which the peak is centered at $540 \mathrm{~nm}$. The peak at $540 \mathrm{~nm}$ became sharper with increasing time due to the rapid production of stable AuNPs. Singh et al. (2010)[48] reported similar results in their study related to AuNPs, which supported the presence of synthesized AuNPs in the solution as evidenced by absorbance at $540 \mathrm{~nm}$. From FTIR results, it is clear that the biomolecular capping occurred onto the surface of green synthesized AuNPs. The presence of proteins, carbohydrates, and phenols is responsible for the stable AuNPs synthesis and this also prevents the agglomeration of biosynthesized AuNPs. Four intense peaks ranging from $10^{\circ}$ to $90^{\circ}$ at a $2 \theta$ angle were revealed in the XRD pattern. When this spectrum was compared with the standard, it confirmed the formation of AuNPs from the cell-free extract of Nostoc sp. strain HKAR-2, which was crystalline. Due to the lack of impurities, the synthesized AuNPs were pure and of high quality, which was further supported by the fact that no extra peaks were found in the spectrum. Data of X-ray diffraction pattern showed $2 \theta$ values at 111, 200, 220, and 311 (JCPDS no.04-0784). The peaks of the Xray diffraction pattern were broad around their bases, indicating that the AuNPs are in nano size. The zeta potential mainly depends upon the $\mathrm{pH}$ and the electrolytic concentration of the dispersion, and -2.39mV charge on AuNPs supports the stability of NPs in physiological saline $\mathrm{pH}$. DLS was observed to be $255.5 \mathrm{~nm}$. The morphology of the green synthesized AuNPs was demonstrated by SEM. The SEM images showed that the particles were spherical and had a bead-like appearance. SEM images showed that the two spherical beads were aggregated together due to the presence of Vander Waals forces and magnetic interactions among the AuNPs. These SEM results also matched with the results of Sobczak-Kupiec et al. (2011)[49]. The TEM images of AuNPs confirmed the size of NPs to be between 10-100 nm, which were stable and spherical in shape, and a difference in size is generally observed in the case of green synthesized NPs. Some differences in the size of NPs in TEM and DLS might be due to the covering of biomolecules onto the NPs. AuNPs find tremendous applications in the field of biomedicine [50-57]. In the present study, The antibacterial activity of AuNPs was tested against two plant bacterial strains, i.e., $R$. solanacearum and $X$. campastris. AuNPs showed a zone of inhibition $(\sim 10 \mathrm{~mm})$ against both bacterial strains, and this activity might be attributed due to the small size but larger surface area of AuNPs, which provide a better bacterial surface contact and high penetrating power. Due to this, AuNPs bind to the cell wall of bacteria, which is made up of peptidoglycan, $\mathrm{N}$-acetyl muramic acid, and $\mathrm{N}$-acetyl glucosamine, causing the defacing and degradation of the cell wall and, finally, death of the bacteria [47]. The drug delivery system can minimize the toxic level of the drug during the treatment [58]. The antifungal activity of NPs depends mainly on the particle size. Due to small particle size, NPs 
possess a larger surface area, increasing their interaction with the membrane proteins. NPs diffuse directly through the cell membrane to the inside of the cell, where it reacts with the sulfur-containing proteins and the phosphorus-containing bases in the DNA. This inhibits the cellular process like replication, protein synthesis and cell repair machinery repair, which lead to cell death [59]. The antitumor property of biosynthesized AuNPs was screened against MCF7 breast cancer cell line. It was found that AuNPs effectively killed the tumor cells at increasing concentrations. The $\mathrm{IC}_{50}$ for AuNPs was found to be $250 \mu \mathrm{g} / \mathrm{mL}$. AuNPs do not show very efficient cytotoxic activity, but due to higher density, inert nature, and ability to carry a high amount of drug, they can be used to treat cancer [60-62].

\section{Conclusions}

In summary, AuNPs have been successfully synthesized biologically using the cyanobacterial cell-free extract, which has good reducing potential. We used different parameters for the optimum synthesis of AuNPs. Biosynthesized AuNPs inhibited the fungal and bacterial growth and also showed antitumor activity. Overall, the work is cheap and ecofriendly for the synthesis of AuNPs, which could be used in various applications such as cancer diagnosis and as antimicrobial agents.

\section{Funding}

Arun S. Sonker is thankful to the University Grants Commission, New Delhi, India, for financial support in the form of fellowship (UGC-JRF-276/S-01). Jainendra Pathak (09/013/0515/2013-EMR-I) is thankful to the Council of Scientific and Industrial Research, New Delhi, India, for the financial support in the form of fellowships.

\section{Acknowledgments}

The authors acknowledge the Department of Physics, BHU, and Department of Metallurgical Engineering, IIT, BHU, for the help in the characterization of nanoparticles. We are also thankful to Dr. Dinesh Singh, Division of Plant Pathology, IARI, New Delhi, Prof. R. S. Upadhyay, and Prof. N. K. Dubey, Department of Botany, BHU, for providing the bacterial, fungal strains, and essential oil, respectively. A special note of thanks goes to Manendra Pachauri, Priyanka Rathour, and Dhananjay K. Yadav for their help in screening the activities of nanoparticles.

\section{Conflicts of Interest}

The authors declare no conflict of interest.

\section{References}

1. Li, H.; Rothberg, L. Colorimetric detection of DNA sequences based on electrostatic interactions with unmodified gold nanoparticles. Proc. Natl. Acad. Sci. U.S.A. 2004, 10, 14036-14039, https://doi.org/10.1073/pnas.0406115101.

2. Sonker, A.S.; Richa; Pathak, J.; Rajneesh; Pandey, A.; Chatterjee, A.; Sinha, R.P. Bionanotechnology: past, present and future. In New Approaches in Biological Research, Sinha R.P., Richa, Eds.; Nova Science Publishers, USA, 2017; 99-141.

3. Sonker, A.S.; Richa; Pathak, J.; Rajneesh; Kannaujiya, V.K.; Sinha, R.P. Characterization and in vitro antitumor, antibacterial and antifungal activities of green synthesized silver nanoparticles using cell extract of Nostoc sp. strain HKAR-2. Can. J. Biotech. 2017, 1, 26-37, https://doi.org/10.24870/cjb.2017-000103. 
4. Le, G. M.; Paquirissamy, A.; Gargouri, D.; Fadda, G.; Testard, F.; Aymes-Chodur, C.; Jubeli, E.; Pourcher, T.; Cambien, B.; Palacin, S.; Renault, J.-P.; Carrot, G. Irradiation effects on polymer-grafted gold nanoparticles for cancer therapy. ACS Appl. Bio. Mater. 2019, 2, 144-154, https://doi.org/10.1021/acsabm.8b00484.

5. Lin, X.; Liu, S.; Zhang, X.; Zhu, R.; Yang, H. An ultrasound activated vesicle of janus au-mno nanoparticles for promoted tumor penetration and sono-chemodynamic therapy of orthotopic liver cancer. Angew. Chem. Int. Ed. Engl. 2019, 59, 1682-1688, https://doi.org/10.1002/anie.201912768.

6. Pathak, J.; Rajneesh; Ahmed, H.; Singh, D.K.; Pandey, A.; Singh, S.P.; Sinha, R.P. Recent developments in green synthesis of metal nanoparticles utilizing cynobacterial cell factories. In Nanomaterials in Plants, Algae and Microorganisms: Concepts and Controversies, Tripathi, D.K., Ahmad, P., Sharma, S., Chauhan, D.K., Dubey N.K., Eds.; Academic Press, 2019; 237-265, https://doi.org/10.1016/B978-0-12-811488-9.00012-3.

7. Sztandera, K.; Gorakiewicz, M.; Klajnert-Maculewicz, B. Gold nanoparticles in cancer treatment. Mol. Pharm. 2019, 16, 1-23, https://doi.org/10.1021/acs.molpharmaceut.8b00810.

8. Zheng, J.; Peng, C.; Xu, J.; Yu, M.; Ning, X.; Huang, Y.; Peng, C.; Xu, J.; Yu, M.; Ning, X.; Huang, Y.; Du, B.; Hernandez, E.; Kapur, P.; Hsieh, J.-T.; Zheng, J. Tuning in vivo transport of anticancer drugs with renalclearable gold nanoparticles. Angew. Chem. Int. Ed. Engl. 2019, 58, 8479-8483, https://doi.org/10.1002/anie.201903256.

9. Aslan, K.; Lakowicz, J.; Geddes, C. Nanogold-plasmon-resonance-based glucose sensing. Anal. Biochem. 2004, 330, 145-155, https://doi.org/10.1016/j.ab.2004.03.032.

10. Letfullin, R.; Joenathan, C.; George, T. Laser-induced explosion of gold nanoparticles: potential role for nano-photothermolysis of cancer. Nanomedicine $\quad \mathbf{2 0 0 6 ,} \quad 1, \quad 473-480$, https://doi.org/10.2217/17435889.1.4.473.

11. Hu, J.; Wang, Z.; Li, J. Gold nanoparticles with special shapes: controlled synthesis, surface-enhanced Raman scattering, and the application in biodetection. Sensors 2007, 7, 3299-3311, https://doi.org/10.3390/s7123299.

12. Skrabalak, S.E.; Chen, J.; Sun, Y.; Lu, X.; Au, L.; Cobley, C.M.; Xia, Y. Gold nanocages: synthesis, properties and applications. Acc. Chem. Res. 2008, 41, 1587-1595, https://doi.org/10.1021/ar800018v.

13. Xu, X.; Stevens, M.; Cortie, M.B. In situ precipitation of gold nanoparticles onto glass for potential architectural applications. Chem. Mater. 2004, 16, 2259-2266, https://doi.org/10.1021/cm034744y.

14. Huang, X.; El-Sayed, I.H.; Qian, W.; El-Sayed, M.A. Cancer cell imaging and photothermal therapy in the near-infrared region by using gold nanorods. J. Am. Chem. Soc. 2006, 128, 2115-2120, https://doi.org/10.1021/ja057254a.

15. Hauck, T.S.; Jennings, T.L.; Yatsenko, T.; Kumaradas, J.C.; Chan, W.C.W. Enhancing the toxicity of cancer chemotherapeutics with gold nanorod hyperthermia. Adv. Mater. 2008, 20, 3832-3838, https://doi.org/10.1002/adma.200800921.

16. Borkowska, M.; Siek, M.; Kolygina, D.V.; Sobolev, Y.I.; Lach, S.; Kumar, S.; Cho, Y.K.; KandereGrzybowska, K.; Grzybowski, B.A. Targeted crystallization of mixed-charge nanoparticles in lysosomes induces selective death of cancer cells. Nat. Nanotechnol. 2020, 15, 331-341, https://doi.org/10.1038/s41565020-0643-3.

17. Riedel, R.; Mahr, N.; Yao, C.; Wu, A.; Yang, F.; Hampp, N. Synthesis of gold-silica core-shell nanoparticles by pulsed laser ablation in liquid and their physico-chemical properties towards photothermal cancer therapy. Nanoscale 2020, 12, 3007-3018, https://doi.org/10.1039/C9NR07129F.

18. Wang, Z.; Chen, Q.; Zhong, Y.; Yu, X.; Wu, Y.; Fu, F. A multicolor immunosensor for sensitive visual detection of breast cancer biomarker based on sensitive nadh-ascorbic-acid-mediated growth of gold nanobipyramids. Anal. Chem. 2020, 92, 1534-1540, https://doi.org/10.1021/acs.analchem.9b04828.

19. Zheng, Y.; Zhang, Y.; Zhang, T.; Cai, H.; Xie, X.; Yang, Y.; Quan, J.; Wu, H. AuNSs@Glycopolymer-ConA hybrid nanoplatform for photothermal therapy of hepatoma cells. Chem. Eng. J. 2020, 389, 124460, https://doi.org/10.1016/j.cej.2020.124460.

20. Lazarides, A.A.; Lance; Kelly, K.; Jensen, T.R.; Schatz, G.C. Optical properties of metal nanoparticles and nanoparticle aggregates important in biosensors. J. Mol. Struct. 2000, 529, 59-63, https://doi.org/10.1016/S0166-1280(00)00532-7.

21. Köhler, J.M.; Csáki, A.; Reichert, J.; Möller, R.; Straube, W.; Fritzsche, W. Selective labeling of oligonucleotide monolayers by metallic nanobeads for fast optical readout of DNA-chips. Sens. Actuators B. Chem. 2001, 76, 166-172, https://doi.org/10.1016/S0925-4005(01)00619-0. 
22. Ankamwar, B.; Chaudhary, M.; Murali, S. Gold nanotriangles biologically synthesized using tamarind leaves extract and potential application in vapor sensing. Inorg. Nano-Met. Chem. 2005, 35, 19-26, https://doi.org/10.1081/SIM-200047527.

23. Pileni, M.P. Fabrication and physical properties of self-organized silver nanocrystals. Pure Appl. Chem. 2000,72, 53-65, https://doi.org/10.1351/pac200072010053.

24. Sun, Y.P.; Atorngitjawat, P.; Meziani, M.J. Preparation of silver nanoparticles via rapid expansion of water in carbon dioxide microemulsion into reductant solution. Langmuir 2001, 17, 5707-5710, https://doi.org/10.1021/la0103057.

25. Nair, B.; Pradeep, T. Coalescence of nanoclusters and formation of submicron crystallites assisted by Lactobacillus strains. Cryst. Growth Des. 2002, 2, 293-298, https://doi.org/10.1021/cg0255164.

26. Willner, I.; Baron, R.; Willner, B. Growing metal nanoparticles by enzymes. J. Adv. Mater. 2006, 18, 11091120, https://doi.org/10.1002/adma.200501865.

27. Vigneshwaran, N.; Ashtaputre, N.M.; Varadarajan, P.V.; Nachane, R.P.; Paraliker, K.M.; Balasubramanya, R.H. Biological synthesis of silver nanoparticles using the fungus Aspergillus flavus. Mater. Lett. 2007, 61, 1413-1418, https://doi.org/10.1016/j.matlet.2006.07.042.

28. Shankar, S.S.; Rai, A.; Ankamwar, B.; Singh, A.; Ahmad, A.; Sastry, M. Biological synthesis of triangular gold nanoprisms. Nat. Mater. 2004, 3, 482-488, https://doi.org/10.1038/nmat1152.

29. MubarakAli, D.; Gopinath, V.; Rameshbabu, N.; Thajuddin, N. Synthesis and characterization of CdS nanoparticles using C-phycoerythrin from the marine cyanobacteria. Mater. Lett. 2012, 74, 8-11, https://doi.org/10.1016/j.matlet.2012.01.026.

30. Rajneesh; Singh, S.P.; Pathak, J.; Sinha, R.P. Cyanobacterial factories for the production of green energy and value-added products: An integrated approach for economic viability. Renew. Sust. Energ. Rev. 2017, 69, 578-595, https://doi.org/10.1016/j.rser.2016.11.110.

31. Pathak, J.; Rajneesh; Maurya, P.; Singh, S.P.; Häder, D.-P.; Sinha, R.P. Cyanobacterial farming for environment friendly sustainable agriculture practices: Innovations and perspectives. Front. Environ. Sci. 2018, 6, 1-7, https://doi.org/10.3389/fenvs.2018.00007.

32. Lengke, M.F.; Fleet, M.E.; Southam, G. Morphology of gold nanoparticles synthesized by filamentous cyanobacteria from gold(I)-thiosulfate and gold(III)-chloride complexes. Langmuir 2006, 22, 2780-2787, https://doi.org/10.1021/la052652c.

33. Lengke, M.; Ravel, B.; Fleet, M.E.; Wanger, G.; Gordon, R.A.; Southam, G. Mechanisms of gold bioaccumulation by filamentous cyanobacteria from gold (III)-chloride complex. Environ. Sci. Technol. 2006, 40, 6304-6309, https://doi.org/10.1021/es061040r.

34. Brayner, R.; Barberousse, H.; Hernadi, M.; Djedjat, C.; Yepremian, C.; Coradin, T.; Livage, J.; Fiévet, F.; Couté, A. Cyanobacteria as bioreactors for the synthesis of Au, Ag, Pd, and Pt nanoparticles via an enzymemediated route. J. Nanosci. Nanotechnol. 2007, 17, 2696-2708, https://doi.org/10.1166/jnn.2007.600.

35. Rastogi, R.P.; Kumari, S.; Han, T.; Sinha, R.P. Molecular characterization of hot spring cyanobacteria and evaluation of their photoprotective compounds. Can. J. Microbiol. 2012, 58, 719-727, https://doi.org/10.1139/w2012-044.

36. Rippka, R.; Deruelles. J.; Waterbury, J.B.; Herdman, M.; Stanier, R.Y. Generic assignments, strain histories and properties of pure cultures of cyanobacteria. Microbiology 1979, 111, 1-61, https://doi.org/10.1099/00221287-111-1-1.

37. Kedia, A.; Prakash, B.; Mishra, P.K.; Dubey, N.K. Antifungal and antiaflatoxigenic properties of Cuminum cyminum (L.) seed essential oil and its efficacy as a preservative in stored commodities. Int. J. Food Microbiol. 2014, 168, 1-7, https://doi.org/10.1016/j.ijfoodmicro.2013.10.008.

38. Muller, R.H.; Akkar, A. Drug nanocrystals of poorly soluble drugs. In Encyclopedia of Nanoscience and Nanotechnology, Nalwa H.S., Ed.; American Scientific Publishers, Stevenson Ranch, 2004; 627-638.

39. Khan, T.; Ullah, N.; Khan, M.A.; Mashwani, Z.R.; Nadhman, A. Plant-based gold nanoparticles: a comprehensive review of the decade-long research on synthesis, mechanistic aspects and diverse applications. Adv. Colloid Int. Sci. 2019, 272, 102017, https://doi.org/10.1016/j.cis.2019.102017.

40. Khanna, P.; Kaur, A.; Goyal, D. Algae-based metallic nanoparticles: synthesis, characterization and applications. J. Microbiol. Methods 2019, 163, 105656, https://doi.org/10.1016/j.mimet.2019.105656.

41. Nishanthi, R.; Malathi, S.; Paul, J.S.; Palani, P. Green synthesis and characterization of bioinspired silver, gold and platinum nanoparticles and evaluation of their synergistic antibacterial activity after combining with different classes of antibiotics. Mater. Sci. Eng. C. 2019, 96, 693-707, https://doi.org/10.1016/j.msec.2018.11.050. 
42. Venditti, I. Engineered gold-based nanomaterials: morphologies and functionalities in biomedical applications. A mini review. Bioengineering 2019, 6, 53, https://doi.org/10.3390/bioengineering6020053.

43. Kalabegishvili, T.; Kirkesali, E.; Rcheulishvili, A.; Ginturi, E.; Murusidze, I.; Kuchava, N.; Bagdavadze, N.; Tsertsvadze, G.; Gabunia, V.; Frontasyeva, M.V.; Pavlov, S.S.; Zinicovscaia, I.; Raven, M.J.; Seaga, N.M.F.; Faanhof, A. Synthesis of gold nanoparticles by blue-green algae Spirulina platensis. Adv. Sci. Eng. Med. 2012, 4, 1-7.

44. Parial, D.; Patra, H.K.; Roychoudhury, P.; Dasgupta, A.K.; Pal, R. Gold nanorod production by cyanobacteria-a green chemistry approach. J. Appl. Phycol. 2012, 24, 55-60, https://doi.org/10.1007/s10811010-9645-0.

45. Rösken, L.M.; Cappel, F.; Körsten, S.; Fischer, C.B.; Schönleber, A.; van Smaalen, S.; Geimer, S.; Beresko, C.; Ankerhold, G.; Wehner, S. Time-dependent growth of crystalline $\mathrm{Au}^{0}$-nanoparticles in cyanobacteria as self-reproducing bioreactors: 2. Anabaena cylindrical. Beilstein J. Nanotechnol. 2016, 7, 312-327, https://doi.org/10.3762/bjnano.7.30.

46. Roychoudhury, P.; Ghosh, S.; Pal, R. Cyanobacteria mediated green synthesis of gold-silver nanoalloy. J. Plant. Biochem. Biot. 2016, 25, 73-78, https://doi.org/10.1007/s13562-015-0311-0.

47. Grace, A.N.; Pandian, K. Antibacterial efficacy of aminoglycosidic antibiotics protected gold nanoparticlesA brief study. Colloids Surf, A. Physicochem. Eng. Asp. 2007, 297, 63-70, https://doi.org/10.1016/j.colsurfa.2006.10.024.

48. Singh, A.K.; Talat, M.; Singh, D.P.; Srivastava, O.N. Biosynthesis of gold and silver nanoparticles by natural precursor clove and their functionalization with amine group. J. Nanoparticle Res. 2010, 12, 1667-1675, https://doi.org/10.1007/s11051-009-9835-3.

49. Sobczak-Kupiec, A.; Malina, D.; Zimowskaa, M.; Wzorek, Z. Characterization of gold nanoparticles for various medical application. Dig. J. Nanomater. Bios. 2011, 6, 803-808.

50. Azharuddin, M.; Zhu, G.H.; Das, D.; Ozgur, E.; Uzun, L.; Turner, A.P.; Patra, H.K. A repertoire of biomedical applications of noble metal nanoparticles. Chem. Comm. 2019, 55, 6964-6996, https://doi.org/10.1039/C9CC01741K.

51. Fuller, M.A.; Köper, I. Biomedical applications of polyelectrolyte coated spherical gold nanoparticles. Nano. Converg. 2019, 6, 11, https://doi.org/10.1186/s40580-019-0183-4.

52. Loynachan, C.; Soleimany, A.P.; Dudani, J.S.; Lin, Y.; Najer, A.; Bekdemir, A.; Chen, Q.; Bhatia, S.N.; Stevens, M.M. Renal clearable catalytic gold nanoclusters for in vivo disease monitoring. Nat. Nanotechnol. 2019, 14, 883-890, https://doi.org/10.1038/s41565-019-0527-6.

53. Ni, C.; Zhou, J.; Kong, N.; Bian, T.; Zhang, Y.; Huang, X.; Xiao, Y.; Yang, W.; Yan, F. Gold nanoparticles modulate the crosstalk between macrophages and periodontal ligament cells for periodontitis treatment. Biomaterials 2019, 206, 115-132, https://doi.org/10.1016/j.biomaterials.2019.03.039.

54. Pissuwan, D.; Camilla, G.; Mongkolsuk, S.; Cortie, M.B. Single and multiple detections of foodborne pathogens by gold nanoparticle assays. WIREs Nanomed. Nanobiotechnol. 2019, 12, 1584, https://doi.org/10.1002/wnan.1584.

55. Ramalingam, V. Multifunctionality of gold nanoparticles: plausible and convincing properties. Adv. Colloid Int. Sci. 2019, 271, 101989, https://doi.org/10.1016/j.cis.2019.101989.

56. Falahati, M.; Attar, F.; Sharifi, M.; Saboury, A.A.; Salihi, A.; Aziz, F.M.; Kostova, I.; Burda, C.; Priecel, P.; Lopez-Sanchez, J.A; Laurent, S. Gold nanomaterials as key suppliers in biological and chemical sensing, catalysis, and medicine. Biochim. Biophys. ActaGen. Subj. 2020, 1864, 129435, https://doi.org/10.1016/j.bbagen.2019.129435.

57. Hu, X.; Zhang, Y.; Ding, T.; Liu, J.; Zhao, H. Multifunctional gold nanoparticles: A novel nanomaterial for various medical applications and biological activities. Front. Bioeng. Biotechnol. 2020, 8, 990, https://doi.org/10.3389/fbioe.2020.00990.

58. Zawrah, M.F.; Abd El-Moez, S.I. Antimicrobial activities of gold nanoparticles against major foodborne pathogens. Life Sci. 2011, 8, 37-44.

59. Tan, Y.N.; Lee, K.H.; Su, X. Study of single-stranded DNA binding protein-nucleic acid interactions using unmodified gold nanoparticles and its application for detection of single nucleotide polymorphisms. Anal. Chem. 2011, 83, 4251-4257, https://doi.org/10.1021/ac200525a.

60. Ghodake, G.; Kim, D.Y.; Jo, J.H.; Jang, J.; Lee, D.S. One-step green synthesis of gold nanoparticles using casein hydrolytic peptides and their anticancer assessment using the DU145 cell line. J. Ind. Eng. Chem. 2016, 33, 185-189, https://doi.org/10.1016/j.jiec.2015.10.001. 
61. Song, J.; Kim, J.; Hwang, S.; Jeon, M.; Jeong, S.; Kim, C.; Kim, S. "Smart" gold nanoparticles for photoacoustic imaging: an imaging contrast agent responsive to the cancer microenvironment and signal amplification via pH-induced aggregation. Chem. Comm. 2016, 52, 8287-8290, https://doi.org/10.1039/C6CC03100E.

62. Song, S.; Hao, Y.Z.; Yang, X.Y.; Patra, P.; Chen, J. Using gold nanoparticles as delivery vehicles for targeted delivery of chemotherapy drug fludarabine phosphate to treat hematological cancers. J. Nanosci. Nanotechnol. 2016, 16, 2582-2586, https://doi.org/10.1166/jnn.2016.12349. 